\title{
Horizontal and vertical profiles of light hydrocarbons in sea water related to biological, chemical and physical parameters
}

\author{
By M. RATTE*, C. PLASS-DÜLMER, R. KOPPMANN and J. RUDOLPH, Institut für \\ Atmosphärische Chemie, Forschungszentrum Jülich, 52425, Jülich, Germany
}

\begin{abstract}
In situ-measurements of light $\left(\mathrm{C}_{2}-\mathrm{C}_{4}\right)$ nonmethane hydrocarbons (NMHC) in sea water were performed during a ship cruise in spring 1991 in the Mediterranean, the Atlantic and the North Sea. The investigated regions were characterized with respect to biological (phytoplankton density, chlorophyll concentration), chemical (concentration of dissolved organic carbon, DOC) and physical parameters (irradiation intensity, wind velocities). These data were analysed for possible correlations with NMHC concentrations. An anticorrelation was found between NMHC concentrations and wind velocity. There were indications of a correlation between alkene concentration and the concentration of photochemically reactive DOC. For regions of low phytoplankton densities, significant positive correlations between biological activity (i.e., chlorophyll concentration and cell density) and the concentrations of all NMHC except ethane were obtained. In contrast, in regions of an active growing phytoplankton bloom the concentrations of all NMHC except n-butane were inversely related to biological activity. In the vertical profiles, the alkanes often showed pronounced concentration maxima in depths of $1-10 \%$ relative light intensity, i.e., at the bottom of the euphotic zone. Alkene concentration maxima occured in the upper layer of the euphotic zone. During periods of very low wind velocities, i.e., low mixing in the ocean surface layer and low emission rates, the concentrations of alkenes in surface water exhibited a distinct diurnal pattern with the concentrations increasing during day time and remaining constant at night.
\end{abstract}

\section{Introduction}

The oceans are known to act as sources for light nonmethane hydrocarbons (NMHC) (Rudolph and Ehhalt, 1981; Bonsang et al., 1988; Plass et al., 1992; Plass-Dülmer et al., 1993, 1995; Donnahue and Prinn, 1993). Recent estimates of NMHC emissions from the oceans range from $50 \mathrm{Mt} / \mathrm{yr}^{-1}$ (Bonsang et al., 1988) down to $2-7 \mathrm{Mt}^{\mathrm{yr}}{ }^{-1}$ (Plass-Dülmer et al., 1993, 1995). Regardless of this large discrepancy of one order of magnitude the oceanic source strength for total NMHC is small compared to the total global NMHC emissions (1000 Mt/yr ${ }^{-1}$ including isoprene and

\footnotetext{
- Corresponding author.
}

terpenes; Ehhalt and Rudolph, 1984). However, due to the short atmospheric life times of most of the NMHC these substances do not persist long enough to allow long range transport processes from continental regions to remote ocean areas. Therefore, depending on the actual magnitude of the oceanic NMHC source, the chemistry of reactive compounds in the marine atmosphere may be substantially influenced by oceanic NMHC emissions (Rudolph and Ehhait, 1981; Bonsang et al., 1990; Koppmann et al., 1992; Donahue and Prinn, 1993). Consequently, for the understanding and description of the chemistry of the remote marine atmosphere, the magnitude of oceanic NMHC emissions should be known with sufficient accuracy. However, the large regional and seasonal variability of oceanic NMHC concentra- 
tions causes a high variability in the existing source strength estimates (Plass-Dülmer et al., 1995). Due to these shortcommings, recently the number of investigations concerning the production mechanism of NMHC in sea water increased. From our present understanding alkenes in sea water are produced via a photochemical transformation of dissolved organic carbon (DOC), with the DOC probably being released by phytoplankton (Wilson et al., 1970; Schobert and Elstner, 1980; Lee and Baker, 1992; Ratte et al., 1993). Therefore, correlations between alkene concentrations in sea water on the one hand and irradiation intensity, DOC-concentration and biological activity on the other hand can be expected. In this paper a comprehensive data set is presented and the existing related investigations are summarized. Up to now no clear dependences were observed and the published results do not yet present a clear picture. Based on our own data set-which for the first time covers a wide range of biological activity-possible reasons are discussed.

\section{Experiment}

The measurements were performed during the NATAC-91 cruise (North Atlantic Atmospheric Chemistry) in April and May 1991 aboard the Ukrainean research vessel ERNST KRENKEL. The cruise track is shown in Fig. 1. Most of the measurements were made in four different regions, each covering an area of about $25 \times 25 \mathrm{~km}^{2}$, called polygons. In each polygon the vessel stayed for about 8 days. The coordinates and the program of measurements are summarized in Table 1.

The NMHC concentrations were measured insitu using a stripping chamber, where the filtered (glassfibre filters, pore size $0.8 \mu \mathrm{m}$ ) sea water samples were purged with ultrapure Helium for $30 \mathrm{~min}$ at a flow rate of $100 \mathrm{ml} \mathrm{min}^{-1}$. The stripped hydrocarbons were enriched cryogenically at liquid nitrogen temperature and analysed by FID/GC (flame ionisation detector gas chromatography). The stripping efficiencies were checked by repeated stripping procedures; for the $C_{2}$ to $C_{4}$

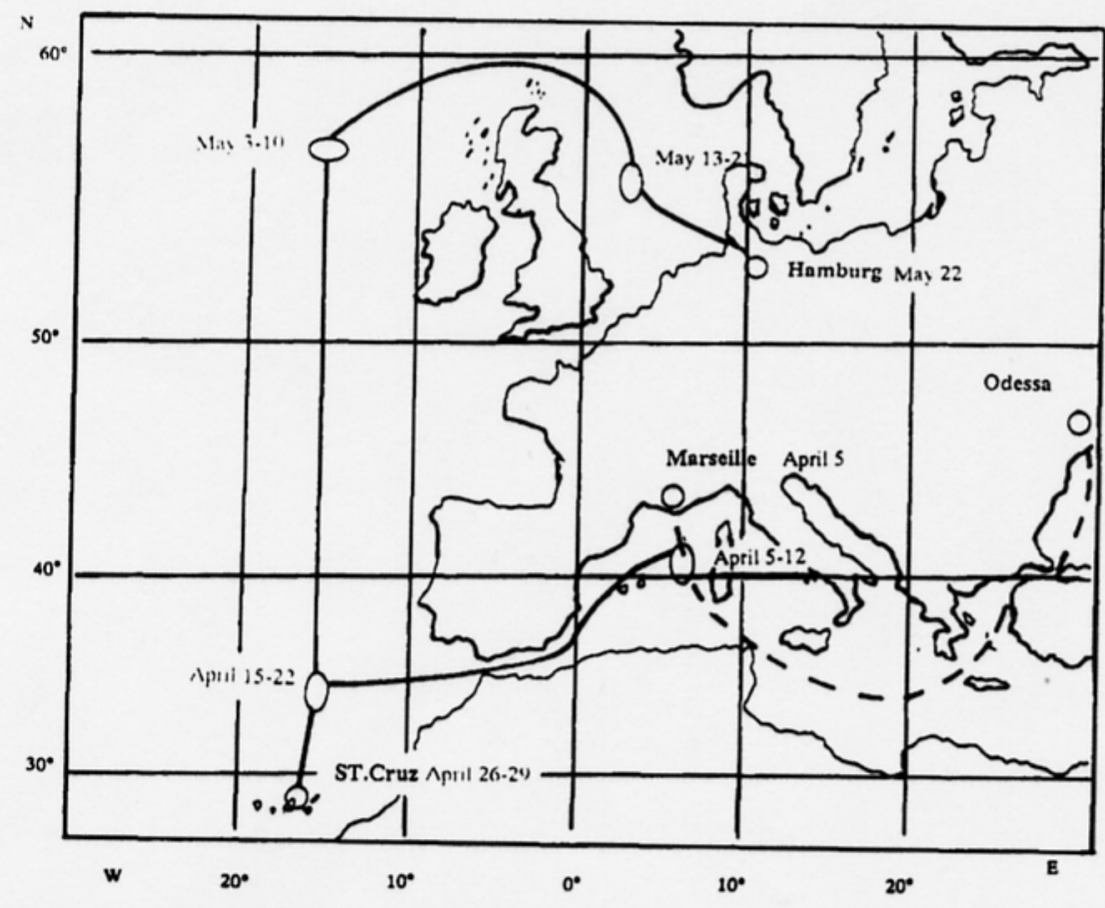

Fig. 1. Cruise track of the ERNST KRENKEL during expedition NATAC-91 in April and May 1991. Circles: Position of the four polygons. For coordinates and program of the four polygons see Table 1. 
Table 1. Measurements during NATAC-91

\begin{tabular}{|c|c|c|c|c|c|}
\hline Date & $\begin{array}{l}\text { Location of the } \\
\text { investigated region }\end{array}$ & $\begin{array}{l}\text { Name of the } \\
\text { investigated region }\end{array}$ & surface & $\begin{array}{l}\text { Measurements } \\
\text { vertical } \\
\text { profile }\end{array}$ & $\begin{array}{c}\text { diumal } \\
\text { variation }\end{array}$ \\
\hline 5-12 April & $5^{\circ} \mathrm{E}, 42^{\circ} \mathrm{N}$ & Mediterranean-polygon & $\mathbf{x}$ & & \\
\hline 15-22 April & $13^{\circ} \mathrm{W}, 37^{\circ} \mathrm{N}$ & Mid-Atlantic-polygon & $\mathbf{x}$ & $\mathbf{X X}$ & $\mathbf{X}^{\mathbf{2}} \mathbf{X}^{\mathbf{b}}$ \\
\hline 3-10 May & $15^{\circ} \mathrm{W}, 57^{\circ} \mathrm{N}$ & North Atlantic-polygon & $\mathbf{x}$ & $\mathrm{XX}$ & \\
\hline 13-21 May & $5^{\circ} \mathrm{E}, 56^{\circ} \mathrm{N}$ & North Sea-polygon & $\mathbf{x}$ & $\mathbf{x x}$ & $\mathbf{X}^{\mathbf{c}}$ \\
\hline
\end{tabular}

a, b 17-18 April, mean wind velocity $4.8 \pm 2.2 \mathrm{~ms}^{-1}$; (a) $2.5 \mathrm{~m}$ depth; (b) $40 \mathrm{~m}$ depth.

c $16-18 \mathrm{May}$, mean wind velocity $4.4 \pm 2.7 \mathrm{~ms}^{-1}$; surface.

hydrocarbons they generally exceeded $97 \%$. All materials in contact with the sample were stainless steel or glass. The detection limits were below 6 pmol $1^{-1}$ except 1 -butene with $11 \mathrm{pmol}^{-1}$. The reproducibility of the measurements was $4 \%$ to $7 \%$ except for 1-butene with $12 \%$. Calibration was done by comparison with reference air of known concentrations, which was cryogenically enriched and analysed as described above. The analytical system is described in detail by Rudolph et al. (1989) and Plass et al. (1991). The instruments were located in a laboratory container on the front deck of the research vessel.

For most of the measurements sea water was pumped continuously from a stainless steel inlet at the bow of the ship to the analytical instrument. The depth of the inlet was about $2.5 \mathrm{~m}$ below the water surface. A lubricant free pump was used in order to avoid contamination of the samples (Johnson KR-SPY 2071). Any contamination would have been detected by the typical hydrocarbon pattern, namely alkanes and aromatic compounds. Additionally, no differences in NMHC pattern or concentrations were observed between samples taken from the continuous inlet line and a stainless steel bucket. Samples for vertical profiles were taken individually with a depth sampler consisting of evacuated stainless steel containers (21) and a stainless steel inlet tube. A glass fibre filter $(0.6 \mu \mathrm{m})$ was inserted in the inlet tubes in order to avoid organisms and particles to enter the sample. The valves controlling the sampling procedures were operated pneumatically. The depth sampler is described in detail by Plass-Dülmer et al. (1993). For each vertical profile up to 6 samples were taken.

The sampling depths covered the whole euphotic zone, i.e., the layer where light intensity is sufficient for phytoplankton net production (down to $1 \%$ of surface light intensity). Because of different turbidity of the water in different regions the absolute depth of the euphotic zone is highly variable. The sampling depths were defined by the relative light intensity $(75 \%, 30 \%, 16 \%, 8 \%, 1 \%$ and $0.1 \%$ ). The optical density of the water was determined with the Secchi-disc. This white disc with a diameter of $30 \mathrm{~cm}$ is lowered into the water. The depth, where it becomes unvisible is called the Secchi-depth. Parsons et al. (1984a) give an empirical equation to calculate the extinction coefficient $k$ of the water from the Secchi-depth $S$ :

$k=1.7 / S$.

Using the extinction coefficient $k$ and assuming vertically constant $k$-values in the euphotic layer, the absolute depth of a given relative light intensity can be calculated following Lambert-Beer's law.

The analysis of the samples started immediatly after collection. Since one measurement took about two hours, the depth samples had to be stored up to 10 hours. As shown by Plass-Dülmer et al. (1993) NMHC concentrations remain stable within this time period.

Diurnal variations of NMHC concentrations were measured in different depths during periods of very low wind velocity, i.e., low water turbulence and low NMHC emission rates (see Table 1). Samples from the ocean surface layer were taken from the bow of the ship with a stainless steel bucket of two liters volume.

Every morning, water samples from different depths were taken and phytoplankton density and species composition as well as chlorophyll concentration were determined aboard the ship (Kreschewnik, private communication). For 
chlorophyll measurements parallel to the NMHC depth profiles the filters in the inlet lines of the depth sampler were frozen and analysed in the laboratory after the cruise following the method of Parsons et al. (1984a).

DOC-concentrations were measured from water samples which were filtered (aluminium oxide filters, pore size $0.2 \mu \mathrm{m}$, Anotec Separations), acidified with $\mathrm{H}_{2} \mathrm{SO}_{4}$ to $\mathrm{pH} \mathrm{1-2}$ and stored in the dark at $6^{\circ} \mathrm{C}$. The total amount of DOC was analysed at the Max-Planck-Institut für Meteorologie, Hamburg, (Spitzy, personal communication) using high temperature combustion in an oxygen atmosphere at a platinum catalyst (Ionics Instruments, USA), similar to the method described by Sugimura and Suzuki (1988). For some samples also another method was applied which determines the photochemical reactive amount of DOC: the DOC was oxidized by ultraviolett light emitted by a $100 \mathrm{~W}$ mercury low pressure lamp ( $85 \%$ emission at $254 \mathrm{~nm}, 15 \%$ at $185 \mathrm{~nm}$ ) (Dünnfilm-UV-Reaktor, Gräntzel company, Karlsruhe, Germany). For both methods the experimental error is estimated to be about $20 \%$.

\section{Results}

\subsection{Phytoplankton densities}

The phytoplankton populations in the four polygons were characterized by different states of the spring phytoplankton bloom (Table 2). In the Mediterranean polygon small phytoplankton species up to $10 \mu \mathrm{m}$ diameter like Coccolithophores and Phaeocystis spec. dominated. The mean cell density was $8 \times 10^{3}$ cells $1^{-1}$. A suc-
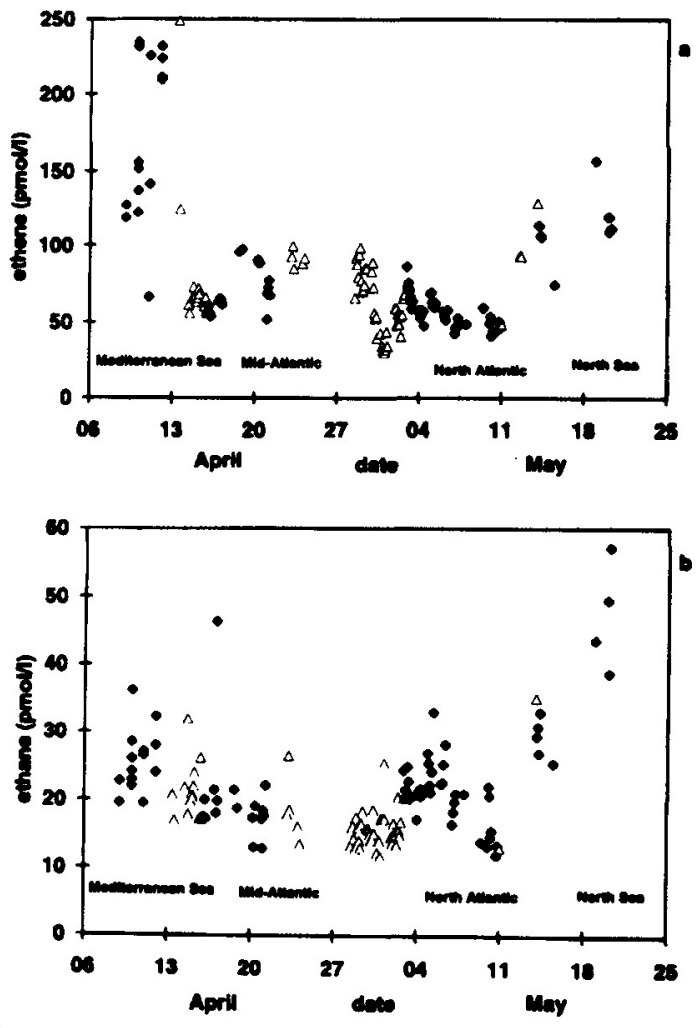

Fig. 2. Horizontal distribution of oceanic concentrations of ethene (a) and ethane (b), measured during NATAC-91. As the abscissa a time scale derived from the cruise track is used instead of coordinates (see Table 1 and Fig. 1). Full symbols: measurements in the polygons. Open symbols: measurements during the transfer routes.

cession of phytoplankton as it is known for the Atlantic ocean and the North Sea does not occur in the Mediterranean sea (Parsons et al., 1984b). In the Mid-Atlantic polygon a growing population

Table 2. Biological data (mean, $95 \%$ confidence intervall in brackets) and average depth of $1 \%$ of surface light intensity, i.e., the euphotic zone in the four polygons; the depth of $I \%$ relative light intensity was calculated using the absorption coefficient determined with the Secchi-disc

\begin{tabular}{lccc}
\hline \multicolumn{1}{c}{ Polygon } & $\begin{array}{c}\text { Chlorophyll a } \\
\text { concentration } \\
\left(\mu \mathrm{g} \mathrm{I}^{-1}\right)\end{array}$ & $\begin{array}{c}\text { Cell density } \\
10^{3}\left(\text { cells } ~^{-1}\right)\end{array}$ & $\begin{array}{c}\text { Depth of } \\
\text { euphotic zone } \\
(\mathrm{m})\end{array}$ \\
\hline Mediterranean Sea & $1.4(1.1-1.7)$ & $8.1(1.7-14.5)$ & 25 \\
Mid-Atlantic & $0.35(0.3-0.4)$ & $14.6(7.7-21.5)$ & 47 \\
North Atlantic & $3.5(2.9-4.1)$ & $7800(5600-9900)$ & 19 \\
North Sea & $0.64(0.5-0.7)$ & $7.0(5.2-8.8)$ & 32 \\
\hline
\end{tabular}


of diatoms had reached a mean cell density of $15 \times 10^{3}$ cells $1^{-1}$. An extremely pronounced bloom of diatoms was found in the North Atlantic polygon with cell densities of about $7800 \times 10^{3}$ cells $1^{-1}$. The bloom was dominated by the genera Chaetoceros, Nitzschia and Thalassiosira. In the North Sea polygon the main phytoplankton genera were dinoflagellates with cell densities of about $7 \times 10^{3}$ cells $1^{-1}$, hence the second stage of the phytoplankton succession typical for the spring bloom in this region (Parson et al., 1984b) was observed. Besides the phytoplankton density also the chlorophyll concentration and the depth of the euphotic layer showed pronounced variations between the different polygons (Table 2).

\subsection{Horizontal profiles of NMHC concentrations}

About 140 ocean water samples from the inlet line were analysed. Fig. 2 shows the horizontal distribution of the ethane and ethene concentrations. The highest ethane concentrations with nearly $60 \mathrm{pmol}^{-1}$ were observed in the North Sea, maximum ethene concentrations with nearly $250 \mathrm{pmol}^{-1}$ occured in the Mediterranean Sea. In these areas also the largest variabilities were observed. On the average, in the Mid-Atlantic polygon and the North Atlantic polygon the concentrations were about two to three times lower. The concentrations of $C_{3}$ and $C_{4}$ hydrocarbons followed similar patterns but generally at lower levels. The concentration of acetylene was more ore less constant at about $20 \mathrm{pmol}^{-1}$. Table 3 summarizes the surface water NMHC concentrations obtained during NATAC-91.

\subsection{Correlations}

(a) Correlation with biological parameters. A weak anticorrelation of most hydrocarbon concentrations with chlorophyll concentrations exists, if all data points are considered (Fig. 3, Table 4a). Similar results are found for the NMHC concentrations and the cell densities (not shown). These correlations are comparable for averages for the euphotic zone or only single data from certain depths. However, if the data set with the pronounced phytoplankton bloom (North Atlantic polygon, black circles in Fig. 3) is excluded, for all compounds except ethane a highly significant positive correlation between the NMHC concentrations and biological activity is obtained (Table 4a). In spite of the significant correlation coefficient the chlorophyll concentration can

Table 3. Concentrations of NMHC (pmoll $\left.{ }^{-1}\right)$ in surface water $(2.5 \mathrm{~m}$ depth) during the cruise NATAC-9I

\begin{tabular}{cccccccc}
\hline Region & Ethene & Ethane & Acetylene & Propene & Propane & $1-B u t e n e$ & n-Butane \\
\hline $\begin{array}{c}\text { Pol I } \\
n\end{array}$ & $170.2 \pm 53.1$ & $25.7 \pm 4.6$ & $14.5 \pm 4.3$ & $103.2 \pm 39.6$ & $19.9 \pm 7.2$ & $123.4 \pm 39.1$ & $39.2 \pm 25.1$ \\
T 1 $\rightarrow 2$ & $68.5 \pm 17$ & $21.1 \pm 4.2$ & $21.4 \pm 5.2$ & $39.9 \pm 9.1$ & $11.5 \pm 1.8$ & $32.4 \pm 19.2$ & $10.2 \pm 5.8$ \\
$n$ & 14 & 14 & 14 & 15 & 15 & 20 & 14 \\
Pol 2 & $72.1 \pm 14.8$ & $20.0 \pm 7.2$ & $20.7 \pm 3.5$ & $50.4 \pm 16.1$ & $11.2 \pm 2.1$ & $51.1 \pm 19.8$ & $14.1 \pm 12.9$ \\
$n$ & 17 & 17 & 17 & 17 & 17 & 16 & 17 \\
T 2 $\rightarrow 3$ & $61.8 \pm 19.6$ & $15.7 \pm 2.5$ & $20.1 \pm 3.8$ & $31.1 \pm 14.1$ & $7.4 \pm 1.9$ & $21.7 \pm 5.3$ & $3.7 \pm 2.0$ \\
$n$ & 37 & 37 & 37 & 37 & 37 & 22 & 22 \\
Pol 3 & $56.8 \pm 10.2$ & $20.9 \pm 4.4$ & $26.8 \pm 2.0$ & $27.3 \pm 14.6$ & $32.6 \pm 11.6$ & $22.7 \pm 5.8$ & $4.9 \pm 2.0$ \\
$n$ & 36 & 36 & 36 & 36 & 36 & 33 & 32 \\
Pol 4 & $112.5 \pm 18.9$ & $44.5 \pm 19.5$ & $22.9 \pm 6.5$ & $62.0 \pm 10.3$ & $15.6 \pm 3.0$ & $45.5 \pm 6.3$ & $11.1 \pm 2.7$ \\
$n$ & 11 & 11 & 11 & 11 & 11 & 11 & 11 \\
all data & $79.5 \pm 41.3$ & $23.8 \pm 19.5$ & $21.7 \pm 5.4$ & $44.2 \pm 27.1$ & $11.5 \pm 10.3$ & $40.5 \pm 33.9$ & $11.9 \pm 15.2$ \\
$n$ & 137 & 137 & 135 & 138 & 138 & 122 & 124 \\
\hline
\end{tabular}

Mean \pm standard deviation and number of samples $(n)$. Pol $=$ polygon, $T=$ transfer route; Pol $1=$ Mediterranean polygon, Pol 2: Mid-Atlantic polygon; Pol 3: North Atlantic polygon; Pol 4: North Sea polygon. For the transfer from Pol 3 to Pol 4 no data are available. 

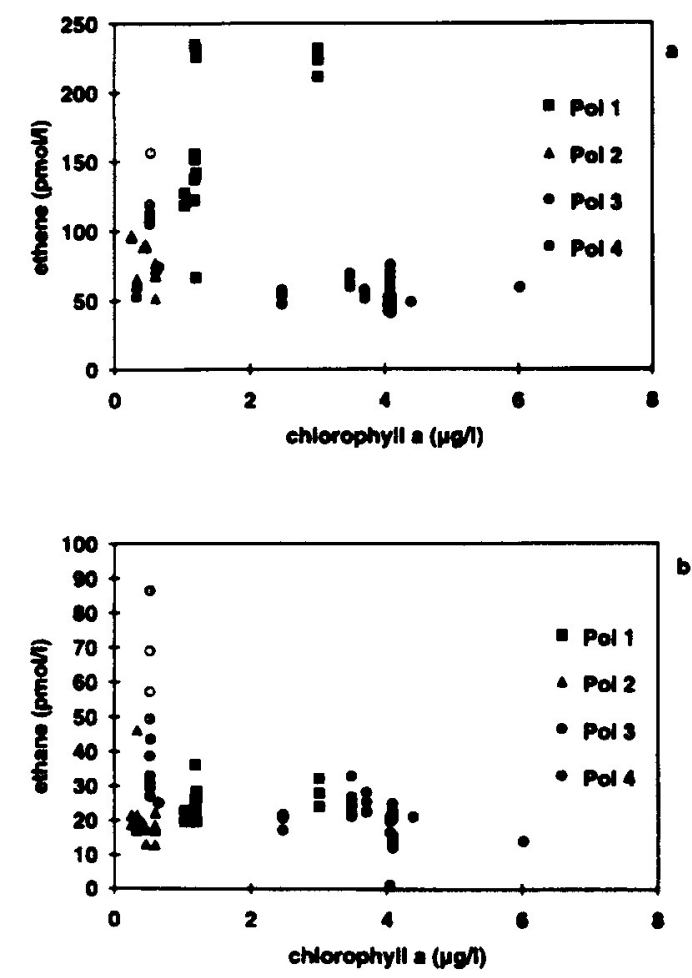

Fig. 3. Concentration of ethene (a) and ethane (b) in $2.5 \mathrm{~m}$ depth versus mean concentration of chlorophyll in the euphotic zone. Polygon $1=$ Mediterranean Sea, Polygon 2 = Mid-Atlantic, Polygon 3 = North Atlantic, Polygon $4=$ North Sea.

explain only $40 \%$ to $55 \%$ of the variability of the alkene concentrations, for the alkanes it only accounts for $20 \%$ to $30 \%$ of the variability.

(b) Correlation with DOC. In Fig. 4 the relationships between the concentrations of DOC and ethane or ethene, respectively, are shown. No significant correlations exist in case of the total amount of DOC (Fig. 4a, b, Table 4a). In contrast to this, our results show a significant linear correlation between the concentrations of $\mathrm{C} 2-\mathrm{C} 3$ hydrocarbons and the amount of the photochemically reactive part of DOC (Fig. 4c, d, Table 4a), explaining about $50 \%$ of the variability of NMHC concentrations. However, the data set of simultaneous NMHC- and DOC-measurements is relativly small and each of the correlations seem to be dominated by the data point with the highest hydrocarbon concentration. If this data point is excluded, for ethene even for the reduced data set a significant correlation with the photochemical reactive amount of DOC is obtained (Table 4a). In this case, the photochemically reactive part of DOC accounts for nearly $40 \%$ of the variability of the ethene concentration.

(c) Correlation with wind velocity. It has been suggested that the main loss process for NMHC concentrations in sea water is emission into the atmosphere (Plass et al., 1992; Plass-Dülmer et al., 1995). The emission rates depend on the transfer velocities, which are primarily a function of the wind velocity (Liss and Merlivat, 1986). In the present investigation the durations of the measurement periods at the same location during the cruise were not sufficient for the calculation of long term averages for the emissions. As a compromise, for periods with fairly constant wind velocities for at least $48 \mathrm{~h}$ the emissions were calculated from the transfer velocities based on average wind velocities and the mean NMHC concentrations in $2.5 \mathrm{~m}$ depth. The calculation of transfer velocities was done according to Liss and Merlivat (1986), a Schmidt number correction as described by PlassDülmer et al. (1993) was used. Eight different data sets in the four polygons were obtained by this procedure. The mean wind velocities were between $3.3 \mathrm{~ms}^{-1}$ and $11.6 \mathrm{~ms}^{-1}$. As shown in Table $4 \mathrm{~b}$, except for ethane, negative correlation coefficients are obtained between NMHC concentrations and transfer velocities, which can explain about $40 \%$ of the variability in the alkene concentrations but only $20 \%$ of the variability in the alkane concentrations.

\subsection{Vertical profiles}

Table 5 summarizes the times and conditions for the sampling of the different vertical profiles. Except for the North Sea polygon, the depth of the mixed layer exceeded that of the euphotic zone. In Figs. 5 and 6, the concentrations of alkenes and alkanes are plotted against the relative light intensity.

In most of the profiles, the alkene concentrations in the upper layer of the euphotic zone were slightly elevated compared to depths below $1 \%$ light intensity. In the North Sea polygon a distinct vertical gradient of the alkene concentrations was found with maximum concentrations close to the surface (Fig. 5, profile taken on 18 May). This profile was sampled in the evening of a sunny and calm day (Table 5). 
Table 4. Correlation coefficients for simple linear regression of individual NMHC-concentrations with individual chlorophyll and DOC concentrations $(a)$ and for simple and multiple linear regression of NMHC concentrations with transfer velocity $k_{w}$ and chlorophyll concentration (b); for the latter, from the data set obtained in the present study, 8 time periods $\geqslant 48 \mathrm{~h}$ with fairly constant wind velocities at one location were selected: for these time periods, average transfer velocities, chlorophyll and NMHC concentrations were calculated: (1) including data from all polygons, $n=8$; level of significance $r_{0.05}=0.67$; (2) without the data set from the North Atlantic polygon (phytoplankton bloom) $n=7 ; r_{0.0 s}=0.71$

(a)

\begin{tabular}{|c|c|c|c|c|c|c|}
\hline \multirow[b]{3}{*}{ NMHC } & \multicolumn{2}{|c|}{ Correlation with [ $\mathrm{Chl} \mathrm{a}]$} & \multicolumn{4}{|c|}{ Correlation with [DOC] } \\
\hline & \multirow[t]{2}{*}{$\begin{array}{c}r \text { (all data) } \\
n=75\end{array}$} & \multirow[t]{2}{*}{$\begin{array}{c}r \text { (without P3-data), } \\
n=41,\end{array}$} & \multirow{2}{*}{$\begin{array}{l}r \text { (all data) } \\
n=12 \\
\text { total DOC }\end{array}$} & \multirow{2}{*}{$\begin{array}{l}r \text { (all data) } \\
n=12 \\
\text { UV-DOC }\end{array}$} & \multicolumn{2}{|c|}{$\begin{array}{c}r \text { (without data point at } \\
\text { highest NMHC concentration), } \\
n=11\end{array}$} \\
\hline & & & & & total DOC & UV.DOC \\
\hline ethene & -0.35 & 0.75 & 0.36 & 0.77 & 0.36 & 0.61 \\
\hline propene & -0.45 & 0.62 & 0.35 & 0.64 & 0.35 & 0.25 \\
\hline 1-butene & -0.41 & 0.69 & $0.18^{*}$ & $0.31 *$ & $0.18^{* *}$ & $0.14 * *$ \\
\hline ethane & -0.33 & 0.03 & 0.20 & 0.67 & 0.20 & 0.35 \\
\hline propane & -0.41 & 0.53 & 0.29 & 0.69 & 0.29 & 0.48 \\
\hline n-butane & -0.28 & 0.48 & $0.32 *$ & $0.37^{*}$ & $0.32^{* *}$ & $0.06 * *$ \\
\hline $\begin{array}{l}\text { level of } \\
\text { significance }\end{array}$ & $r_{0.01}=0.296$ & $r_{0.01}=0.398$ & $r_{0.05}=0.58$ & $r_{0.05}=0.58$ & $r_{0.05}=0.60$ & $r_{0.05}=0.60$ \\
\hline
\end{tabular}

$* n=10 ; * * n=9$

(b)

(1)

\begin{tabular}{|c|c|c|c|c|c|c|c|c|}
\hline NMHC & $\begin{array}{c}\text { single } \\
k_{\mathrm{w}}\end{array}$ & $\begin{array}{c}\text { single } \\
r \\
\text { Chl a }\end{array}$ & $\begin{array}{c}\text { multiple } \\
\boldsymbol{R}\end{array}$ & $\begin{array}{c}\text { multiple } \\
R^{2}\end{array}$ & $\begin{array}{c}\text { single } \\
r \\
k_{w}\end{array}$ & $\begin{array}{c}\text { single } \\
r \\
\mathrm{Chl} \mathrm{a}\end{array}$ & $\begin{array}{c}\text { multiple } \\
\boldsymbol{R}\end{array}$ & $\begin{array}{c}\text { multiple } \\
R^{2}\end{array}$ \\
\hline ethene & -0.60 & -0.19 & -0.62 & 0.39 & -0.60 & 0.89 & 0.92 & 0.84 \\
\hline propene & -0.61 & -0.30 & -0.67 & 0.45 & -0.62 & 0.69 & 0.79 & 0.62 \\
\hline 1-butene & -0.50 & -0.09 & n.d. & n.d. & -0.53 & 0.95 & n.d. & n.d. \\
\hline ethane & 0.12 & -0.15 & 0.20 & 0.04 & 0.16 & 0.04 & 0.19 & 0.04 \\
\hline propane & -0.39 & -0.25 & -0.46 & 0.21 & -0.36 & 0.66 & 0.67 & 0.45 \\
\hline n-butane & -0.54 & -0.02 & n.d. & n.d. & -0.53 & 0.95 & n.d. & n.d. \\
\hline
\end{tabular}

Significant correlation coefficients are given in bold type. For levels of significance, see Geigy, (1982). Please note, that a significant correlation coefficient not necessarily explains a large part of the variability $\left(r^{2}\right)$ of the parameter under consideration (Steel and Torrie, 1981); P3-data = data from the North Atlantic polygon (phytoplankton bloom); total $\mathrm{DOC}=\mathrm{DOC}$-concentration measured by thermal oxidation; UV-DOC $=\mathrm{DOC}$-concentration measured by photochemical oxidation; $\mathrm{n} . \mathrm{d} .=\mathrm{not}$ determined, due to some missing data for $\mathrm{C} 4$ concentrations the data is too small. 
Table 5. Times and conditions for sampling of vertical profiles (VP)

\begin{tabular}{lcccccc}
\hline Profile & $\begin{array}{c}\text { Polygon of } \\
\text { sampling }\end{array}$ & Date & Local time & $\begin{array}{c}\text { Wind velocity } \\
\left(\mathrm{m} \mathrm{s}^{-1}\right)^{*}\end{array}$ & $\begin{array}{c}\text { Depth (m) of } \\
\text { euphotic zone** }\end{array}$ & $\begin{array}{c}\text { Depth (m) of } \\
\text { thermocline*** }\end{array}$ \\
\hline VP 1 & Mid-Atlantic & 16 April & $10: 00$ & $10.1 \pm 1.6$ & 40 & $60-70$ \\
VP 2 & Mid-Atlantic & 20 April & $14: 00$ & $7.5 \pm 1.4$ & 40 & $100-150$ \\
VP 3 & North Atlantic & 3 May & $11: 00$ & $6.9 \pm 1.8$ & 16 & $30-50$ \\
VP 4 & North Atlantic & 6 May & $11: 00$ & $9.8 \pm 2.3$ & 19 & $30-50$ \\
VP 5 & North Sea & 15 May & $11: 00$ & $12.1 \pm 2.7$ & 27 & $20-30$ \\
VP 6 & North Sea & 18 May & 22:00 & $3.2 \pm 1.7$ & 38 & $5-15$ \\
\hline
\end{tabular}

* Mean \pm standard deviation for the 24-h period before sampling.

** Depth of $1 \%$ light intensity relative to intensity at the surface.

*** Estimated from temperature profiles.
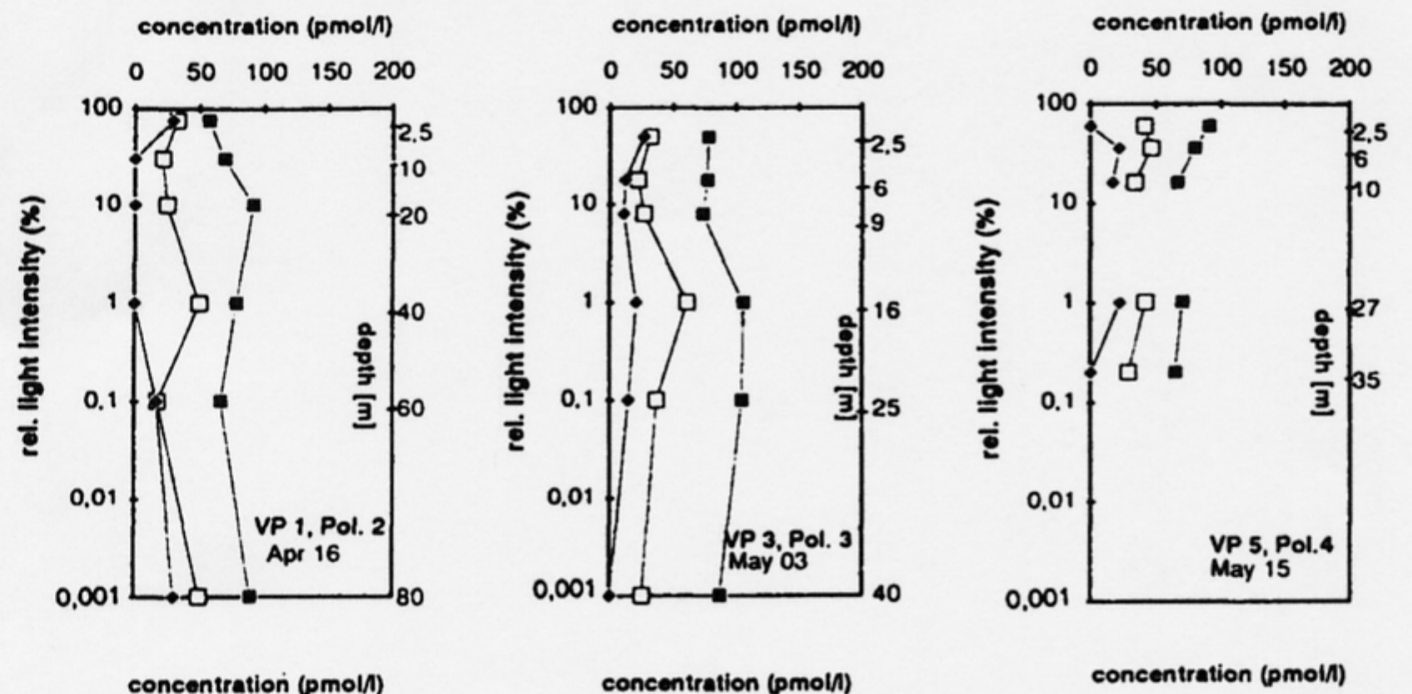

concentration (pmol/)

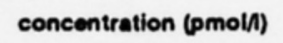

concentration (pmoin)

$\begin{array}{lllll}0 & 50 & 100 & 150 & 200\end{array}$
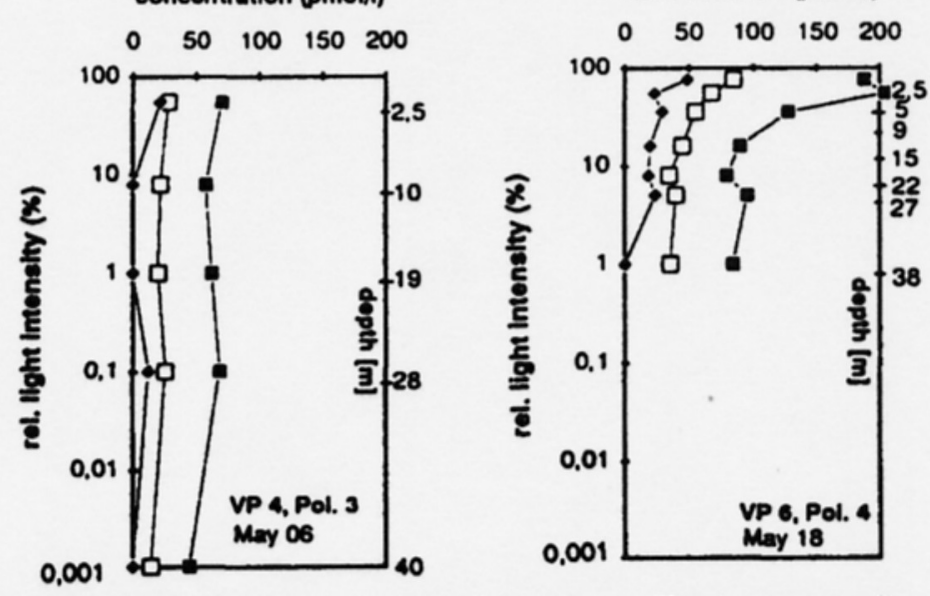

0,00

0,001

Fig. 5. Vertical profiles of alkene concentrations plotted against the relative light intensity. The absolute sampling depths $(m)$ are given at the right axis. Full squares: ethene, open squares: propene, full diamonds: 1-butene. For details of sampling conditions and times see Table 5. 

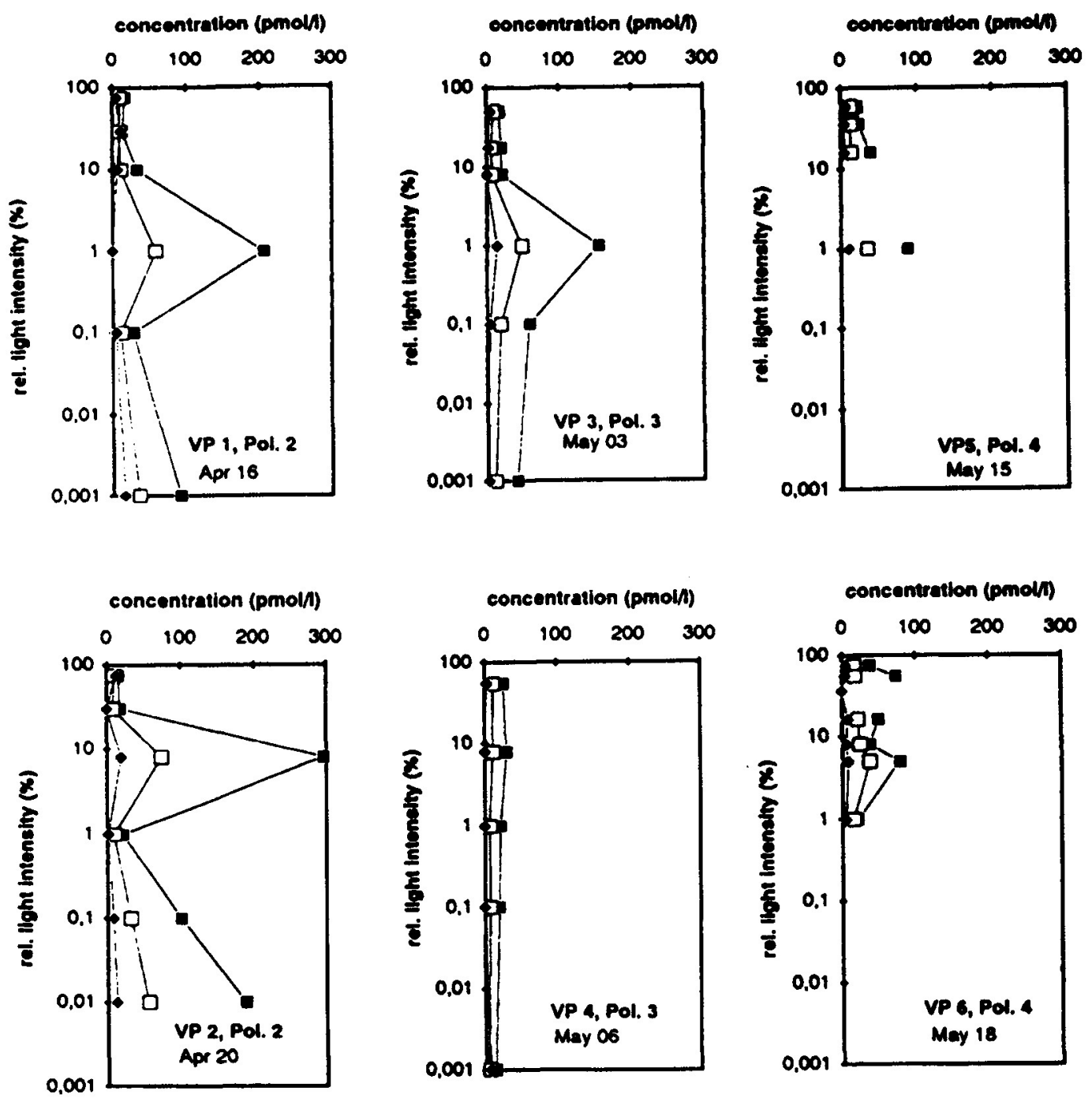

Fig. 6. Vertical profiles of alkane concentrations plotted against the relative light intensity. For absolute sampling depths see Fig. 5. Full squares: ethane, open squares: propane, full diamonds: n-butane. For details of sampling conditions and times see Table 5 .

sity) showed no dependence on the time of the day (Fig. 7a, b). Only at $40 \mathrm{~m}$ depth (i.e., at $1 \%$ light intensity) the concentration of ethane showed a sharp increase in the two samples taken after sunrise, at 7:00 a.m. and 11:00 a.m. (local time) (Fig. 7c). In contrast to this the alkene concentrations at the surface seemed to follow a diurnal pattern with the concentrations increasing during day time and remaining constant at night (Fig. 7d). With increasing depth or decreasing light intensity, respectively, this pattern is weakend (Fig. 7e,f). The concentration of acetylene was found to be about $20 \mathrm{pmol}^{-1}$, regardless of depth and time (not shown). 


\section{alkanes}

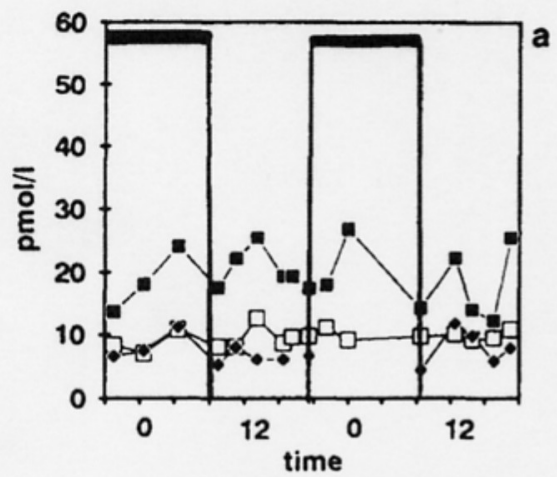

alkenes

surface

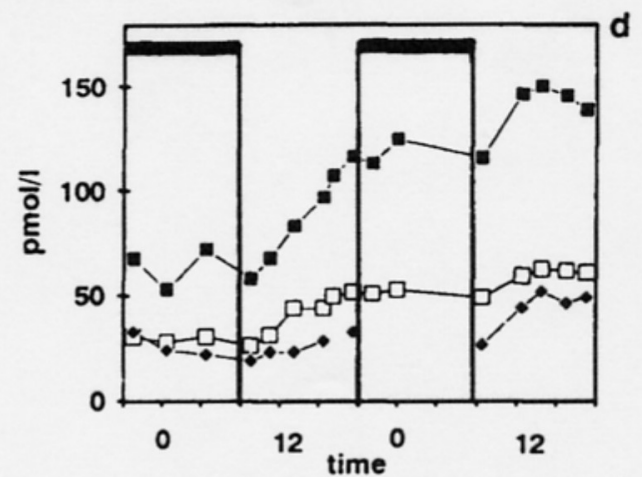

$2.5 \mathrm{~m}$ depth, $75 \%$ rel. light intensity
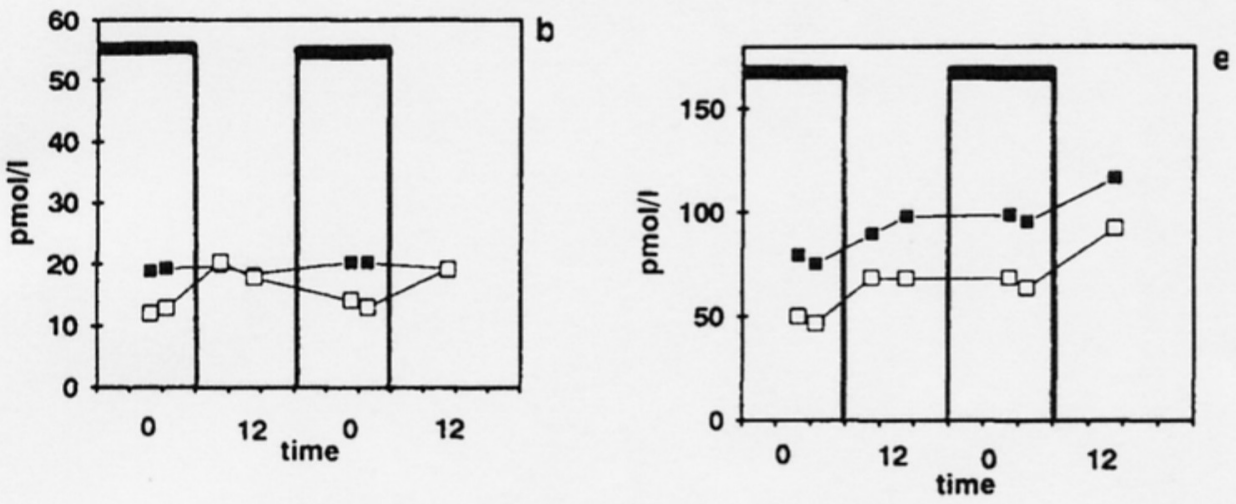

$40 \mathrm{~m}$ depth, $1 \%$ rel. light intensity
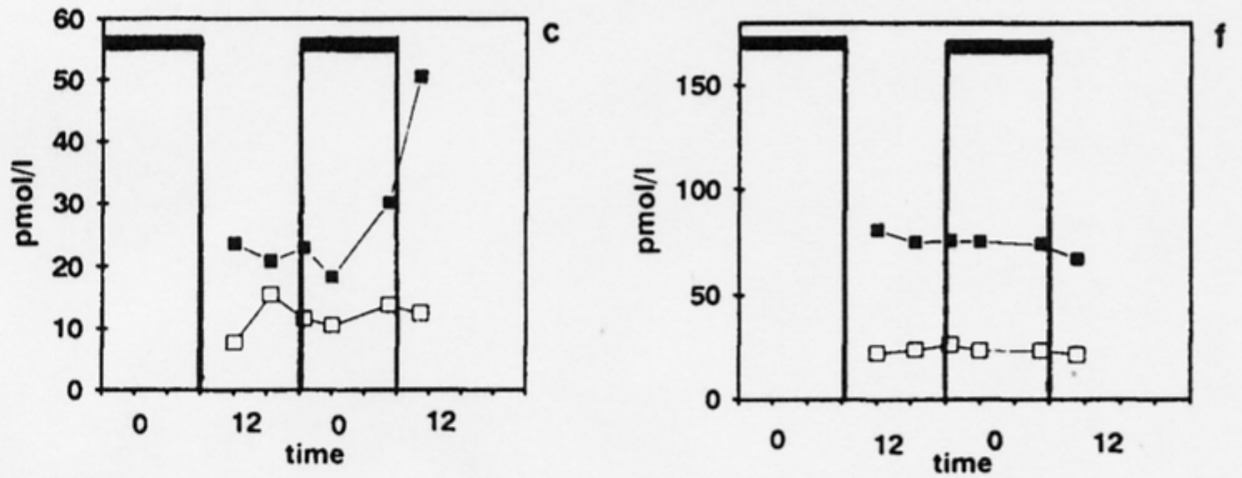

Fig. 7. Diurnal variation of NMHC concentrations: (a, d) at the surface, samples from the North Sea; (b, e) at $2.5 \mathrm{~m}$ depth, i.e., $75 \%$ relative light intensity, samples from the Mid-Atlantic; (c, f) at $40 \mathrm{~m}$ depth, i.e., $1 \%$ relative light intensity, samples from Mid-Atlantic. For coordinates of the sample areas and wind velocities see Table 1. (a-c) alkanes; $(d-f)$ alkenes. Full squares: ethane, ethene; open squares: propane, propene; full diamonds: n-butane, 1-butene (in most cases below the detection limit). The dark bars indicate night. 


\section{Discussion}

\subsection{Diurnal variations}

The measurements of diurnal variations of the NMHC concentrations took place under conditions of very low wind velocities, i.e., losses due to emission to the atmosphere were negligible. In this case, the diurnal variations reflect primarily the NMHC production rates. Generally, the pattern of the diurnal variation in the alkene concentrations confirms the supposed role of light in the alkene production process. In laboratory experiments the wavelengths between 300 and $400 \mathrm{~nm}$ were identified to have the highest quantum yields for the photochemical alkene production (Ratte et al., unpublished results). For further characterization of the diurnal variations we compared the ethene concentrations measured at the ocean surface to the cumulative intensity of light of the wavelengths $300-400 \mathrm{~nm}$ reaching the ocean surface. This wavelength band coincides with the spectral range causing $\mathrm{NO}_{2}$-photolysis in the atmosphere. The $\mathrm{NO}_{2}$-photolysis rates were measured during NATAC-91 (Weber, 1993). As can be seen from Fig. 8, both variables show the same time dependence.

\subsection{Vertical profiles}

Generally, the occurrence of pronounced maxima or strong gradients within the mixed layer points to mechanisms leading to NMHC produc- tion- or loss-rates which occur faster than mixing. From the light dependence of the alkene production process it follows that the production rates should be highest at the ocean surface. Here also the emission to the atmosphere occur. The actual shape of the vertical profile will depend on the relative importance of these processes and the rate of vertical mixing. Consequently, after a period of low wind velocity and high irradiation intensity, distinct vertical gradients of alkene concentrations with maxima close to the surface are to be expected. This pattern indeed was found in the vertical profiles of alkene concentrations measured in the North Sea (Fig. 5). However, just in these cases the euphotic zone was found to be not completely mixed, but exhibited a temperature gradient (Table 5). In the following we will discuss, whether the gradient in alkene concentration may be caused by temperature effects rather than by irradiation effects. For the verticale profile No. 5 taken on May 15th the temperature gradient is of no interest, since the main decrease in alkene concentrations occurs between depths of 2 and $10 \mathrm{~m}$ (Fig. 5), i.e., above the thermocline $(20-30 \mathrm{~m}$, Table 5). In case of the vertical profile No. 6 taken on May 18th the layer of the thermocline $(5-15 \mathrm{~m}$, Table 5) indeed coincides with the layer of maximum decrease of alkene concentrations (Fig. 5). However, both temperature and alkene concentration decrease with increasing water depth, i.e., the lower the temperature, the lower the

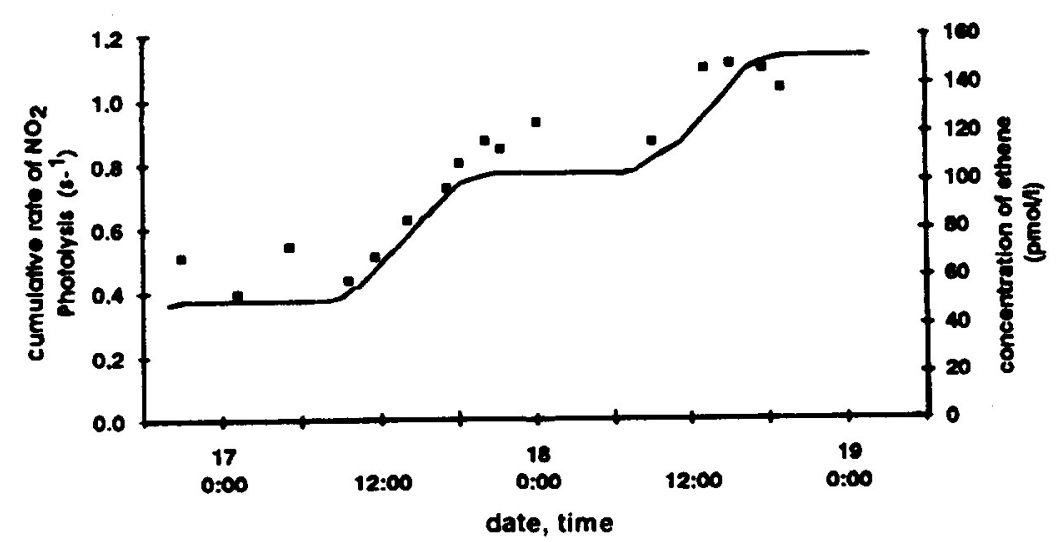

Fig. 8. Relationship between ethene concentration in surface water (full squares) and cumulative $\mathrm{NO}_{2}$-photolysis rate (Weber, 1993, solid line), measured in the North Sea polygon on 16 to $18 \mathrm{May}$. Since the $\mathrm{NO}_{2}$-photolysis is caused by light of the wavelengths $300-400 \mathrm{~nm}$, the $\mathrm{NO}_{2}$-photolysis-rate coincides with the irradiation intensity in this spectral range. The time scale is given in local time (UT plus $2 \mathrm{~h}$ ). 
alkene concentrations. From the temperature dependence of the solubility of gases in sea water the opposite is to be expected, if the temperature would have directly effected the alkene concentration. Moreover, even any indirect temperature effect on alkene concentration seems to be unlikely, since the temperature gradient was in the range of only $0.5^{\circ}\left(8,3^{\circ} \mathrm{C}\right.$ downto $\left.7.8^{\circ} \mathrm{C}\right)$, compared to a gradient in ethene concentration of about $120 \mathrm{pmol}^{-1}$ (about $200 \mathrm{pmol}^{-1}$ down to 80 pmol $^{-1}$ ).

The alkane concentrations often showed pronounced maxima at the lower end of the euphotic zone (in depths with $1 \%-10 \%$ relative light intensity). In these samples, no elevated concentrations of acetylene, benzene and toluene were observed, thus a man made pollution seems to be unlikely. The clear relationship to light intensity points to another explanation. Organisms are usually adapted to certain physiological environmental conditions, e.g., the light intensity, rather than to a certain absolute depth. This points to a relation of the elevated alkane concentrations to biological parameters. Yet, there was no correlation with the chlorophyll concentration nor with the phytoplankton density. There may be a relation to marine bacteria, for which the bottom of the euphotic zone is known as a typical habitat. Within aggregations of these bacteria anoxic conditions can occur (Sorokin, 1971a; b). Linnenbom and Swinnerton (1970) reported elevated alkane concentrations in anoxic areas of the water column. However, since no data of bacteria densities are available this explanation remains hypothetical.

\subsection{Overview over related investigations}

Plass-Dülmer et al. (1995) summarized the presently available NMHC measurements in sea water and looked for correlations with climatological averages of temperature and irradiation as well as for correlations with transfer velocities (based on frequency distributions of wind velocities) and with chlorophyll concentrations (obtained from monthly or seasonally averaged composites of the Coastal Zone Colour Scanner). No significant correlations were obtained except an anticorrelation between alkene concentration and transfer velocity. From the finding that the actual NMHC concentrations in sea water obviously are strongly influenced by transfer velocity, i.e., loss processes due to emission to the atmosphere, Plass-Dülmer et al. (1995) concluded, that possible relationships between NMHC concentrations and parameters involved in the production mechanism are difficult to recognize.

Indeed, the literature data published up to now do not give a clear picture of the correlation between biological activity and NMHC concentrations (Table 6). From measurements in the upwelling areas off the West coast of Africa Zsolnay $(1973,1977)$ calculated significant correlation coefficients of $r=0.63$ and 0.43 , respectively, for the correlation between hydrocarbon concentrations and chlorophyll a concentrations. However, due to the analytical procedure only the sum of nonvolatile hydrocarbons was measured. Since nonfiltered samples were used, the measured hydrocarbons were most likely long-chained constituents of marine phytoplankton (Blumer et al., 1971; Barbier et al., 1973; Osterroht and Petrick, 1982; Osterroht et al., 1983) rather than light hydrocarbons. Plass-Dülmer et al. (1993) measured concentrations of light hydrocarbons as well as phytoplankton biomasses in the upwelling region off the West coast of Africa. The measurements took place in August. They revealed high phytoplankton biomasses but no elevated concentrations of NMHC.

During a cruise in the Pacific Ocean Lamontagne et al. (1976) analysed 400 samples taken in $2 \mathrm{~m}$ depth for light hydrocarbons, chlorophyll, cell number and DOC. The analysis of these data showed significant relationships between the biological parameters and the hydrocarbon concentrations (Table 6). Another data set was provided by Swinnerton et al. (1977). From February to June at two stations off the coast of Florida, biweekly samples were taken and analysed for concentrations of $\mathrm{C}_{2}-\mathrm{C}_{4}$ hydrocarbons and chlorophyll. Our analysis of these data sets showed significant correlations (Table 6).

To sum up, the data obtained in regions of low biological activity and variability (Lamontagne et al., 1976, Swinnerton et al., 1977), i.e., regions of nearly steady state conditions, support the existence of a positive correlation between biological activity and NMHC concentration. The data sets which include regions of high biological activity, i.e., actively growing phytoplankton 


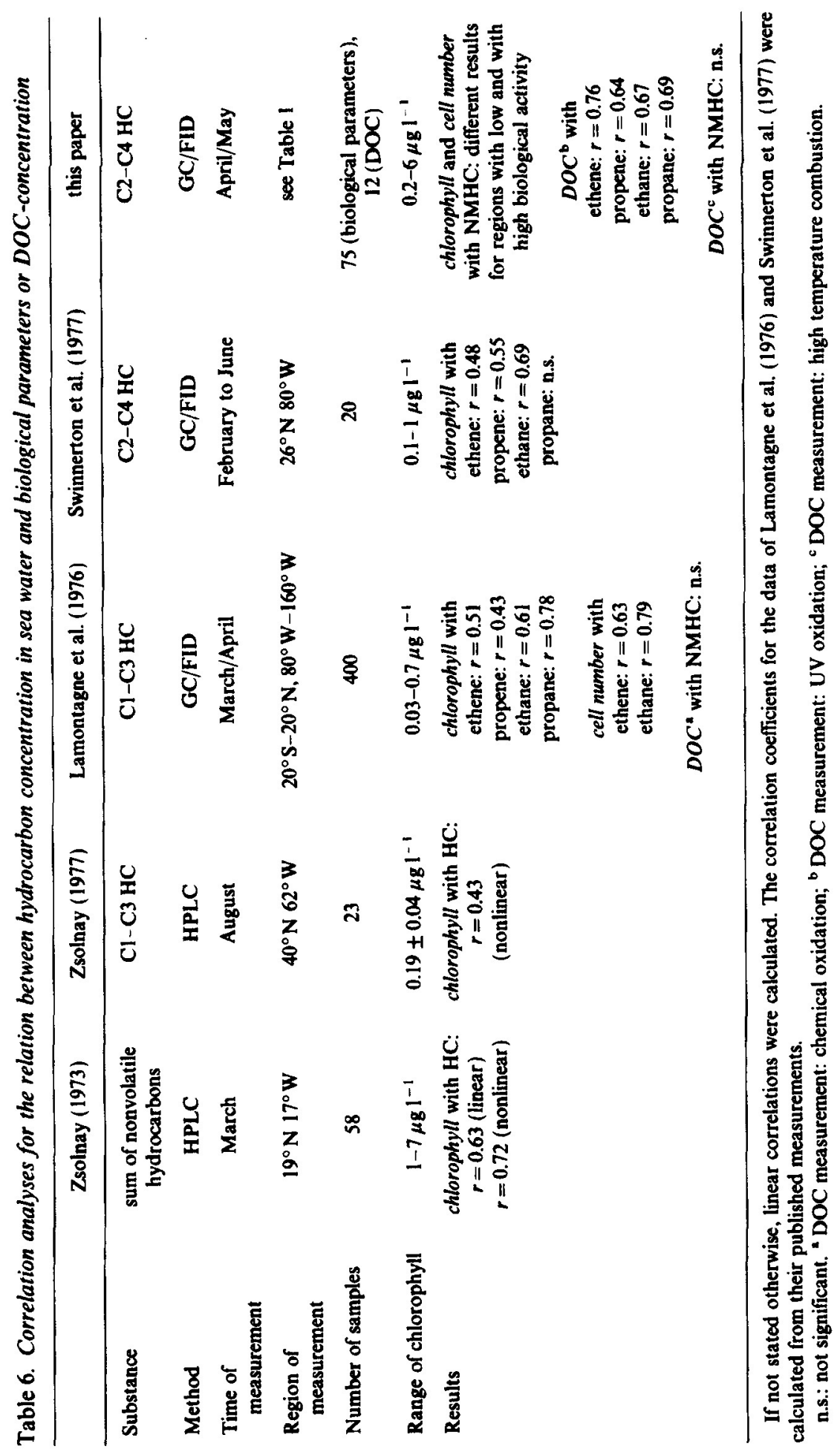


blooms (Plass-Dülmer et al., 1993; this paper) lead to different results. This may be due to a time delay between phytoplankton growth, DOC release and the establishment of a steady state concentration of alkenes. Beyond this, high phytoplankton densities diminish the light intensity in the water column, hence photochemical processes such as alkene production are less effective. Furthermore, at present we neither understand the biological process which accounts for the release of the alkene forming fraction of DOC (e.g., excretion. decomposition) nor do we know the relevant species or growth phase. After all, since in all investigations single parameters account for at best $60 \%$ of the total variability of the NMHC concentrations, it is obvious that not only one parameter affects the actual alkene concentration in sea water. For example, loss processes may obscure possible correlations between alkene concentrations and phytoplankton densities.

\subsection{Correlations calculated using the present data} set

Unfortunatly, in the present study, the procedure to calculate meaningfull transfer velocities for appropriate time periods reduces the data base to 8 data sets (see above). The number of DOC measurements is small, anyway, and most of them were made during the transfer routes. On the other hand, chlorophyll measurements are only available from the polygons. Therefore, a multiple regression can be performed only for NMHC concentrations with transfer velocities and chlorophyll concentrations. For the latter the individual data were averaged over the same time periods as were the transfer velocities. Generally, the variability of the alkene concentrations can be explained much better by these parameters than that of the alkane concentrations (Table 4b). Additionally, the multiple regression confirms, that the correlation is improved considerably if data from regions with a phytoplankton bloom are excluded. In this case, for the ethene concentrations more than $80 \%$ of the variability can be statistically explained by the parameters chlorophyll concentration and transfer velocity. In spite of the small data base, this provides evidence for both the emission to the atmosphere and the phytoplankton being involved in the adjustement of the actual alkene concentrations in sea water.

\section{Summary and Conclusion}

In the present study, the oceanic NMHC concentrations as well as several parameters which are potentially involved in the alkene production mechanism, such as phytoplankton density, DOCconcentration, irradiation intensity (Wilson et al., 1970; Ratte et al., 1993), were measured during a ship campaign. Saturated and unsaturated hydrocarbons in sea water generally exhibit a completely different behaviour. Fairly constant concentrations of acetylene were observed independent on longitude and latitude, time of the day or sampling depth. In contrast to this the alkane concentrations varied considerably, but no commen behaviour could be observed.

Both the light intensity and the concentration of photochemical reactive DOC in sea water are correlated with alkene concentrations. Significant positive correlations between phytoplankton density and alkene concentrations were obtained only for regions of low biological activity. In regions of high biological activity with an actively growing phytoplankton bloom the alkene concentrations showed a weak anticorrelation with phytoplankton density. The present stage of knowledge does not allow to define a clear relationship between biological parameters such as cell density, biomass or concentration of chlorophyll and oceanic alkene concentrations. Further investigations should focus on the time phase relationship between the occurance of a phytoplankton bloom and the development of DOC- and alkene concentrations.

\section{Acknowledgements}

We thank the Institute for Applied Geophysics, Moscow, and the Ukranian Research Center for the Ecology of the Black Sea, Odessa, for the opportunity to participate in NATAC-91. We are grateful to the scientists and the crew of the Ernst Krenkel for their cooperation and especially to $P$. Kreschewnik for providing unpublished biological data. Additionally, we want to thank A. Spitzy, Max-Planck-Institut für Meteorologie, Hamburg, for the measurements of DOC concentration by high temperature catalytic oxidation. 


\section{REFERENCES}

Barbier, M., Joley, D., Saliot, A. and Tourres, D. 1973. Hydrocarbons from sea water. Deep-Sea-Research 20 , 305-314.

Blumer, M., Guillard, R. R. L. and Chase, T. 1971 Hydrocarbons of marine phytoplankton. Mar. Biol. 8, 183-189.

Bonsang, B., Kanakidou, M., Lambert, G. and Monfray, P. 1988. The marine source of $\mathrm{C}_{2}-\mathrm{C}_{6}$ aliphatic hydrocarbons. J. Atm. Chem. 6, 3-20.

Bonsang, B., Lambert, G. and Fontaine, E. 1989. Air sea exchanges of nonmethane hydrocarbons. A contribution to the EUROTRAC subproject Air Sea Exchange (ASE). Eurotrac Annual Report, Int. Sci. Secr. Fraunhofer Inst. Garmisch-Partenkirchen, Germany, 30-35.

Bonsang, B., Kanakidou, M. and Lambert, G. 1990. NMHC in the marine atmosphere: preliminary results of monitoring at Amsterdam Island. J. Atmos. Chem. 11. 169-178.

Donahue, N. M. and Prinn, R. G. 1993. In-situ nonmethane hydrocarbon measurements on SAGA 3. J. Geophys. Res. 98, D9, 16915-16932.

Ehhalt, D. H. and Rudolph, J. 1984. On the importance of light hydrocarbons in multiphase atmospheric systems. Jül-Bericht 1942, ISSN 0366-0885, KFA Jülich.

Geigy Scientific Tables 1982 . Vol. 2, ed. by C. Lentner, Ciba Geigy, Basle, Switzerland.

Koppmann, R., Bauer, R., Johnen, F. J., Plass, C. and Rudolph, J. 1992. The distribution of light nonmethane hydrocarbons over the mid-atlantic: results of the Polarstern cruise ANT VII/1. J. Atmos. Chem. 15, 215-234.

Lamontagne, R. A., Smith, W. D. and Swinnerton, J. W. 1976. Cl-C3 Hydrocarbons and Chlorophyll a concentrations in the equatorial pacific Ocean. Adv. Chem. Ser. 147, 163-171.

Lee, R. F. and Baker, J. 1992. Ethylene and ethane production in an estuarine river: formation from the decomposition of polyunsaturated fatty acids. Mar. Chem. 38, 25-36.

Linnenbom, V. J. and Swinnerton, J. W. 1970. Low molecular weight hydrocarbons and carbon monixide in sea water. In: Organic matter in natural waters (ed. D. W. Hood), University of Alaska Press, Fairbanks, Alaska, 455-467.

Liss, P. S. and Merlivat, L. 1986. Air-sea gas exchange rates: introduction and synthesis. In: The róle of airsea exchange in geochemical cycling (ed. P. BuatMenard). Reidel Publishing Company, Dordrecht, 113-127.

Osterroht, C. and Petrick, G. 1982. Aliphatic hydrocarbons in particulate matter from the baltic sea. Mar. Chem. 11, 55-70.

Osterroht, C., Petrick, G. and Wenck, A. 1983. Seasonal variation of particulate hydrocarbons in relation to biological parameters. Mar. Chem. 14, 175-194.
Parsons, T. R., Yoshiaki, M. and Lalli, C. M. 1984a A manual of chemical and biological methods for seawater analysis. Ist edition. Pergamon Press.

Parsons, T. R., Takahashi, M. and Hargave, B. 1984b. Biological oceanographic processes. 3d edition. Pargamon Press.

Plass, C., Koppmann, R. and Rudolph, J. 1991. Measurements of dissolved nonmethane hydrocarbons in sea water. Fresenius J. Anal. Chem. 339, 746-749.

Plass, C., Koppmann, R. and Rudolph, J. 1992. Light hydrocarbons in the surface water of the mid-atlantic. J. Atm. Chem. 15, 235-251.

Plass-Dülmer, C., Khedim, A., Koppmann, R., Johnen, F. J., Rudolph, J. and Kuosa, H. 1993. Emissions of light nonmethane hydrocarbons from the atlantic into the atmosphere. J. Glob. Biogeochem. Cycles 7, 1, 211-228.

Plass-Dülmer, C., Koppmann, R., Ratte, M. and Rudolph, J. 1995. Light nonmethane hydrocarbons in sea water: an overview. J. Glob. Biogeochem. Cycles, in press.

Ratte, M., Plass-Dülmer, C., Koppmann, R., Rudolph, J. and Denga, J. 1993. Production mechanism of C2-C4 hydrocarbons in sea water: field measurements and experiments. J. Glob. Biogeochem. Cycles 7, 2, 369-378.

Rudolph, J. and Ehhalt, D. H. 1981. Measurements of $C_{2}-C_{5}$ hydrocarbons over the North Atlantic. J. Geophys. Res. 86, C12, 11959-11964.

Rudolph, J., Johnen, F. J., Khedim, A. and Pilwat, G. 1989. The use of automated "on line" gaschromatography for the monitoring of organic trace gases in the atmosphere at low levels. Intern. J. Environm. Anal. Chem. 38, 143-155.

Schobert, B. and Elstner, E. F. 1980. Production of hexanal and ethane by Phaeodactylum tricornutum and its correlation to fatty acid oxidation and bleaching of photosynthetic pigments. Plant. Physiol. 66. 215-219.

Sorokin, Y. I. 1971a. On the role of bacteria in the productivity of tropical oceanic waters. Int. Rev. Ges. Hydrobiol. 56, 1-48.

Sorokin, Y. I. 1971b. Bacterial populations as components of ocanic ecosystems. Mar. Biol. 11, 101-105.

Steel, G. D. and Torrie, J. H. 1981. Principles and procedures of statistics. A biometrical approach. McGrawHill Int. Book Company, London.

Sugimura, Y. and Suzuki, Y. 1988. A high temperature catalytic oxidation method for the determination of non-volatile dissolved organic carbon in sea water by direct injection of a liquid sample. Mar. Chem. 24, 105-131.

Swinnerton, J. W., Lamontagne, R. A. and Bunt, J. S. 1977. Field study of carbon monoxide and light hydrocarbon production related to natural biological processes. Naval Research Laboratory, Report 8099. Washington, DC.

Weber, M. 1993. Nachweis von oxidierten Stickstoff- 
verbindungen und Uberprüfung des photostationären Zustandes in belasteter und unbelasteter Luft. PhD Thesis, University Bonn, Germany.

Wilson, D. F., Swinnerton, J. W. and Lamontagne R. A 1970. Production of carbon monoxide and gaseous hydrocarbons in seawater: relation to dissolved organic carbon. Science 168, 1577-1579.
Zsolnay, A. 1973. Hydrocarbon and chlorophyll a correlation in the upwelling region of West Africa. Deep-Sea Research 20, 923-925.

Zsolnay, A. 1977. Hydrocarbon content and chlorophyll correlation in the waters between Nova Scotia and the Gulf stream. Deep-Sea Research 24, 199-207. 